\title{
EVALUASI UMUR KOMPONEN PENDUKUNG SISTEM KESELAMATAN REAKTOR RISET RSG-GAS
}

\author{
Mike Susmikanti ${ }^{1}$, Entin Hartini ${ }^{1}$, Abdul Hafid ${ }^{1}$, Geni Rina Sunaryo ${ }^{1}$, Endiah Puji Hastuti ${ }^{1}$, \\ Sriyono ${ }^{1}$, Muhamad Subekti ${ }^{1}$, Aep Saepudin ${ }^{2}$, Purwadi ${ }^{2}$ \\ ${ }^{1}$ Pusat Teknologi Keselamatan Reaktor Nuklir, Kawasan Puspiptek, Gd. 80, Setu, Tangerang \\ Selatan, 15310 \\ ${ }^{2}$ Pusat Reaktor Serba Guna, Kawasan Puspiptek, Gd. 31, Setu,, Tangerang Selatan,15310
}

\begin{abstract}
ABSTRAK
EVALUASI UMUR KOMPONEN PENDUKUNG SISTEM KESELAMATAN REAKTOR RISET RSG-GAS. Umur komponen merupakan hal terpenting bagi status komponen setelah beroperasi sekian lama dalam kurun waktu tertentu sehingga dapat diketahui apakah masih dapat berfungsi dengan baik dan apakah perlu dilakukan perawatan secara kontinyu. Saat ini umur komponen dalam kaitannya dengan keselamatan dan manajemen penuaan RSG-GAS masih belum dievaluasi khususnya untuk komponen yang mendukung sistim keselamatan. Penelitian ini bertujuan melakukan evaluasi umur komponen pendukung sistim keselamatan dalam kurun waktu tahun 2005-2015. Kegiatan penelitian meliputi pencarian informasi kegagalan, perbaikan dan perawatan komponen pendukung sistim keselamatan RSGGAS pada teras nomor 55 - 88. Evaluasi umur komponen meliputi uji kecocokan (goodness of fit) dan karakteristik sebaran antara waktu kegagalan dan perbaikan. Selanjutnya dilakukan perhitungan fungsi peluang keandalan dan tingkat resiko yang berkaitan dengan faktor keselamatan, serta peluang komponen akan gagal pada waktu tertentu. Berdasarkan hasil evaluasi ini diperoleh bahwasanya perawatan secara berkala sangat diperlukan.
\end{abstract}

Kata kunci : manajemen penuaan, umur komponen, komponen pendukung sistim keselamatan, kegagalan, perawatan, RSG-GAS

\section{ABSTRACT}

LIFE EVALUATION OF SAFETY SYSTEM SUPPORTING COMPONENTS OF THE RSG-GAS RESEARCH REACTOR. The component life is the most important thing for the component status after operating for a long period of time so that it can be seen whether it can still function properly and whether it needs to be carried out continuously. Currently the component life has not been evaluated in relation to the safety and aging management of RSGGAS. The component life evaluation has not been carried out specifically for components that support the RSG-GAS safety system. This study aims to evaluate the age of the components supporting the safety system in the period 2005-2015. Research activities include searching for information on failure, repair and maintenance of the supporting components of the RSG-GAS safety system on core number 55 to 88. Next the component life evaluation includes goodness of fit test and distribution characteristics between failure time and repairs. Furthermore, the calculation of the reliability probability and risk level functions related to safety factors, as well as the chance of the component will fail at a certain time were performed. Based on the results of this evaluation it is concluded that periodic maintenance is very necessary.

Keywords: aging management, component life, safety system supporting components, failure, maintenance, $R S G-G A S$ 


\section{PENDAHULUAN}

Sesuai RENSTRA BATAN Tahun 2020-2024 dan PTKRN, diperlukan evaluasi reaktor riset RSG-GAS yang telah beroperasi selama lebih dari 30 tahun. Laporan penilaian keselamatan berkala telah dilakukan untuk periode 10 tahun, yaitu tahun 2005 sampai dengan 2015. Laporan operasi reaktor RSG-GAS per Teras tahun 2005 sampai 2015 telah dibuat untuk mendukung penilaian keselamatan berkala, akan tetapi belum dimanfaatkan secara optimal untuk mengevaluasi umur komponen berkaitan dengan manajemen penuaan RSGGAS. Selain itu analisis keandalan telah dilakukan terhadap komponen pendukung sistim keselamatan RSG-GAS. Keandalan komponen harus memperhatikan karakteristik mutu berupa umur komponen. Setiap komponen diharapkan mempunyai nilai keandalan yang tinggi agar aman.

Oleh karena itu evaluasi umur terhadap komponen sistem keselamatan sangat diperlukan dan belum dilakukan dalam manajemen penuaan RSG-GAS yang telah beroperasi hampir 40 tahun. Adapun penelitian untuk mendukung evaluasi umur komponen yang telah dilakukan antara lain telah dibuatnya sistim informasi laporan operasi struktur sistem komponen RSG-GAS [1]. Disamping itu telah dibuat prototipe sistem basis data komponen untuk pengoperasian parameter RSG-GAS [2]. Telah dilakukan analisis keandalan komponen RSG-GAS pada sistem purifikasi KBE01 dan lapisan air hangat KBE02 [3]. Klasifikasi komponen berdasarkan tingkat keselamatan telah dibuat oleh unit jaminan mutu Pusat Reaktor Serba Guna (PRSG) [4]. Demikian pula laporan operasi reaktor, teras nomer 55 sampai 88 untuk kegagalan dan perbaikan komponen RSG-GAS [5]. Klasifikasi keselamatan telah dilakukan untuk struktur dan komponen pada reaktor riset [6]. Disamping itu, analisis keandalan telah dilakukan menggunakan beberapa sebaran peluang kegagalan [7]. Karakteristik umur komponen produk untuk beberapa model sebaran telah dianalisis [8]. Analisa penentuan umur telah dilakukan menggunakan fungsi Mean Residual Life [9]. Modeling untuk empat sebaran peluang serta sebaran robust telah diterapkan untuk beberapa studi kasus [10-13]. Selanjutnya analisis keandalan telah dilakukan untuk beberapa komponen kritis pada sistim pendingin primer serta komponen pendukung sistim keselamatan RSG-GAS [14,15]. Demikian pula analisis keandalan perawatan diterapkan pula pada sub-sistem elektrik, instrumentasi dan kontrol RSG-GAS [16].

Berdasarkan analisis kegiatan yang telah dilakukan di atas, terlihat bahwa evaluasi umur komponen belum dilakukan terhadap komponen pada RSG-GAS terutama pada komponen pendukung sistim keselamatan. Penelitian ini bertujuan melakukan evaluasi umur komponen terhadap komponen 
pendukung sistim keselamatan RSG-GAS.

Komponen pendukung ini merupakan komponen yang mempunyai tingkat keselamatan tinggi yang berhubungan dengan zat radioaktif atau komponen kritis.

\section{TEORI}

Nilai keandalan komponen dinyatakan dengan peluang keandalan, tingkat resiko, rata-rata umur komponen dan umur komponen. Kemampuan hidup komponen dinyatakan dengan keandalan komponen. Peluang komponen berfungsi lebih dari waktu yang telah ditentukan disebut reliabilitas atau keandalan. Evaluasi umur komponen meliputi uji kecocokan (goodness of fit) dan perhitungan karakteristik sebaran antara waktu kegagalan dan perbaikan. Waktu kegagalan merupakan waktu antar dua kegagalan yang berturutan pada suatu komponen. Umur rata-rata komponen merupakan lamanya komponen tersebut mampu berfungsi sampai tiba waktu kegagalan. Model distribusi pada umumnya yang dipakai dan memenuhi kriteria uji kecocokan adalah sebaran Weibull yang merupakan model distribusi umum dan dipergunakan untuk sebaran fungsi tidak linier terhadap waktu t. Fungsi kepadatan peluang distribusi Weibull dinyatakan pada persamaan (1):

$$
f(t)=\frac{\gamma}{\theta} t^{\gamma-1} e^{\frac{t^{\gamma}}{\theta}}
$$

dengan parameter skala $\theta$ (scale) dan parameter bentuk $\gamma$ (shape) yang bernilai positif. Parameter $\theta$ merupakan karakteristik umur, yang menggambarkan sifat umur produk. Sedangkan parameter $\gamma$ menggambarkan bentuk distribusi. Jika nilai $\gamma$ pada distribusi Weibull lebih kecil dari 1, maka diambil shape $\gamma$ sama dengan 1. Untuk sebaran normal diambil shape 3,43927 [8]. Fungsi distribusi kumulatif Weibull diberikan pada persamaan (2) [7],

$$
F(t)=1-e^{-\frac{t^{\gamma}}{\theta}}, \mathrm{t}>0
$$

Fungsi keandalan Weibull terhadap waktu dinyatakan pada persamaan $(3)[8,9]$

$$
R(t)=e^{-\frac{t^{\gamma}}{\theta}}, \mathrm{t}>0
$$

Peluang umur komponen akan gagal pada waktu tertentu, merupakan tingkat resiko kegagalan atau laju kegagalan yang dinyatakan dengan persamaan (4):

$$
h(t)=\frac{f(t)}{1-F(t)}=\frac{\gamma}{\theta} t^{y-1}
$$

Waktu gagal merupakan taksiran waktu antar dua kegagalan yang berturutan pada suatu komponen, dinyatakan pada persamaan (5),

$$
E(t)=\theta^{\frac{1}{\gamma}} \Gamma\left(1+\frac{1}{\gamma}\right)
$$

Sedangkan umur komponen merupakan lamanya komponen masih berfungsi sampai waktu tertentu dinyatakan persamaan (6),

$$
L(\operatorname{Inf})=\frac{1}{R(t)} \int_{t}^{\infty} \tau f(\tau) d \tau
$$




\section{METODOLOGI}

Metode yang digunakan meliputi metoda peluang secara statistik dan matematik serta keandalan komponen menggunakan pemrograman MINITAB dan MATLAB. Hipotesa sebaran yang diuji yaitu sebaran weibull, normal, eksponen dan lognormal. Kegagalan komponen pendukung sistim keselamatan teras 53-88 tahun 20052015 dapat diuji jika mempunyai frekuensi kegagalan lebih dari 3. Perhitungan dilakukan untuk parameter umur rata-rata melalui sebaran waktu kegagalan (Time To Failure). Berikutnya dilakukan perhitungan peluang keandalan, tingkat resiko serta umur rata-rata komponen akan gagal pada waktu tertentu. Metode penelitian meliputi:

- Pencarian informasi kegagalan dan perbaikan komponen pendukung sistim keselamatan teras nomer 53-88 (operasi reaktor tahun 2005-2015)

- $\quad$ Perhitungan Time To Failure (TTF) dari waktu kegagalan berikutnya dan perbaikan sebelumnya

- Uji kecocokan sebaran waktu TTF (Normal, Eksponen, Log-Normal, Weibull menggunakan uji Anderson Darling)

- Perhitungan parameter karakteristik dari sebaran yang sesuai

- Perhitungan nilai keandalan terhadap waktu kegagalan dan perbaikan tahun ke-t dari tahun 2005.
- Perhitungan peluang umur komponen akan gagal pada waktu tertentu dan taksiran waktu antar dua kegagalan yang berturutan pada suatu komponen.

\section{HASIL DAN PEMBAHASAN}

Frekuensi kegagalan dan perbaikan komponen pendukung sistim keselamatan teras nomor 53-88 tahun 2005-2015 ditampilkan pada Tabel 1.

Tabel 1. Frekuensi kegagalan komponen pendukung sistem keselamatan

\begin{tabular}{|c|c|c|c|}
\hline $\begin{array}{c}\text { Sub- } \\
\text { Sistem }\end{array}$ & Deskripsi & $\begin{array}{c}\text { Interval } \\
\text { Perawatan }\end{array}$ & $\begin{array}{l}\text { Frekuensi } \\
\text { kegagalan }\end{array}$ \\
\hline BRV10 & $\begin{array}{c}\text { Emergency } \\
\text { Diesel } \\
\text { Aggregates }\end{array}$ & 6 bulan & 7 \\
\hline BRV20 & $\begin{array}{l}\text { Emergency } \\
\text { Diesel } \\
\text { Aggregates }\end{array}$ & 6 bulan & 11 \\
\hline BRV30 & $\begin{array}{c}\text { Emergency } \\
\text { Diesel } \\
\text { Aggregates }\end{array}$ & 6 bulan & 9 \\
\hline $\begin{array}{l}\text { KBE01 } \\
\text { AP001 }\end{array}$ & $\begin{array}{l}\text { Pump Primary } \\
\text { Purification } \\
\text { System }\end{array}$ & 6 bulan & 9 \\
\hline $\begin{array}{l}\text { KBE01 } \\
\text { AP002 }\end{array}$ & $\begin{array}{l}\text { Pump Primary } \\
\text { Purification } \\
\text { System }\end{array}$ & 6 bulan & 6 \\
\hline $\begin{array}{l}\text { KBE01 } \\
\text { AA068 }\end{array}$ & Shut-off valves & 1 bulan & 5 \\
\hline SMJ10 & $\begin{array}{c}\text { Crane in Reactor } \\
\text { Operation Hall }\end{array}$ & 1 tahun & 5 \\
\hline JKT04 & $\begin{array}{c}\text { Out of core } \\
\text { temperature and } \\
\text { neutron flux } \\
\text { measurement }\end{array}$ & 6 bulan & 5 \\
\hline $\begin{array}{l}\text { JKT02 } \\
\text { CX811 }\end{array}$ & $\begin{array}{c}\text { Neutron Density } \\
\text { Intermediate } \\
\text { Range }\end{array}$ & 6 bulan & 7 \\
\hline $\begin{array}{l}\text { JKT03 } \\
\text { CX811 }\end{array}$ & $\begin{array}{c}\text { Neutron Flux } \\
\text { Density Power } \\
\text { Range }\end{array}$ & 6 bulan & 5 \\
\hline $\begin{array}{l}\text { JKT03 } \\
\text { CX841 }\end{array}$ & $\begin{array}{c}\text { Neutron Flux } \\
\text { Density Power } \\
\text { Range }\end{array}$ & 6 bulan & 4 \\
\hline
\end{tabular}


Nilai Time To Failure antara waktu kegagalan dan perbaikan (TTF) untuk sistem komponen keselamatan BRV10 ditampilkan pada Tabel 2.

Tabel 2. TTF untuk BRV10

\begin{tabular}{cccc}
\hline $\begin{array}{c}\text { Teras } \\
\text { Nomor }\end{array}$ & $\begin{array}{c}\text { BRV10 } \\
\text { Kegagalan }\end{array}$ & Perbaikan & TTF \\
\hline 58 & $08 / 08 / 2006$ & $08 / 08 / 2006$ & 6 \\
68 & $17 / 08 / 2009$ & $17 / 08 / 2009$ & 736 \\
73 & $24 / 11 / 2010$ & $24 / 11 / 2010$ & 408 \\
78 & $25 / 05 / 2012$ & $25 / 05 / 2012$ & 531 \\
85 & $12 / 02 / 2014$ & $12 / 02 / 2014$ & 623 \\
85 & $12 / 03 / 2014$ & $12 / 03 / 2014$ & 14 \\
85 & $02 / 06 / 2014$ & $02 / 06 / 2014$ & 64 \\
\hline
\end{tabular}

Nilai Time To Failure antara waktu kegagalan dan perbaikan (TTF) untuk sistem komponen keselamatan BRV20 ditampilkan pada Tabel 3.

Tabel 3. TTF untuk BRV20

\begin{tabular}{cccc}
\hline $\begin{array}{c}\text { Teras } \\
\text { Nomor }\end{array}$ & $\begin{array}{c}\text { BRV20 } \\
\text { Kegagalan }\end{array}$ & Perbaikan & TTF \\
\hline 62 & $21 / 10 / 2007$ & $21 / 10 / 2007$ & 311 \\
62 & $09 / 12 / 2007$ & $09 / 12 / 2007$ & 49 \\
63 & $16 / 01 / 2008$ & $16 / 01 / 2008$ & 38 \\
66 & $29 / 11 / / 2008$ & $12 / 12 / 2008$ & 318 \\
69 & $10 / 11 / 2009$ & $10 / 11 / 2009$ & 333 \\
69 & $16 / 11 / 2009$ & $16 / 11 / 2009$ & 25 \\
80 & $02 / 11 / 2012$ & $02 / 11 / 2012$ & 1075 \\
83 & $28 / 06 / 2013$ & $28 / 06 / 2013$ & 238 \\
86 & $03 / 12 / 2014$ & $11 / 12 / 2014$ & 523 \\
87 & $26 / 03 / 2015$ & $02 / 04 / 2015$ & 105 \\
88 & $01 / 06 / 2015$ & $01 / 06 / 2015$ & 60 \\
\hline
\end{tabular}

Nilai Time To Failure antara waktu kegagalan dan perbaikan (TTF) untuk sistem komponen keselamatan BRV30 ditampilkan pada Tabel 4.
Tabel 4. TTF untuk BRV30

\begin{tabular}{cccc}
\hline $\begin{array}{c}\text { Teras } \\
\text { Nomor }\end{array}$ & $\begin{array}{c}\text { BRV30 } \\
\text { Kegagalan }\end{array}$ & Perbaikan & TTF \\
\hline 56 & $02 / 04 / 2006$ & $02 / 04 / 2006$ & 314 \\
57 & $14 / 04 / 2006$ & $14 / 04 / 2006$ & 12 \\
57 & $25 / 04 / 2006$ & $25 / 04 / 2006$ & 11 \\
60 & $22 / 04 / 2007$ & $22 / 04 / 2007$ & 362 \\
66 & $12 / 12 / 2008$ & $12 / 12 / 2008$ & 589 \\
69 & $12 / 10 / 2009$ & $12 / 10 / 2009$ & 62 \\
82 & $17 / 04 / 2013$ & $17 / 04 / 2013$ & 1277 \\
\hline
\end{tabular}

Nilai Time To Failure antara waktu kegagalan dan perbaikan (TTF) untuk sistem komponen keselamatan KBE01 AP001 ditampilkan pada Tabel 5.

Tabel 5. TTF untuk KBE01 AP001

\begin{tabular}{cccc}
\hline $\begin{array}{c}\text { Teras } \\
\text { Nomor }\end{array}$ & $\begin{array}{c}\text { KBE01 } \\
\text { AP001 } \\
\text { Kegagalan }\end{array}$ & Perbaikan & TTF \\
\hline 59 & $23 / 01 / 2007$ & $23 / 01 / 2007$ & 1076 \\
65 & $06 / 07 / 2008$ & $06 / 07 / 2008$ & 530 \\
71 & $01 / 04 / 2010$ & $11 / 06 / 2010$ & 634 \\
80 & $12 / 09 / 2012$ & $21 / 09 / 2012$ & 824 \\
85 & $16 / 01 / 2014$ & $20 / 01 / 2014$ & 482 \\
85 & $06 / 02 / 2014$ & $03 / 02 / 2014$ & 17 \\
85 & $25 / 04 / 2014$ & $07 / 05 / 2014$ & 81 \\
86 & $21 / 07 / 2014$ & $25 / 07 / 2014$ & 75 \\
87 & $03 / 02 / 2015$ & $27 / 03 / 2015$ & 193 \\
\hline
\end{tabular}

Nilai Time To Failure antara waktu kegagalan dan perbaikan (TTF) untuk sistem komponen keselamatan KBE01 AP002 ditampilkan pada Tabel 6.

Tabel 6. TTF untuk KBE01 AP002

\begin{tabular}{cccc}
\hline $\begin{array}{c}\text { Teras } \\
\text { Nomor }\end{array}$ & $\begin{array}{c}\text { KBE1 } \\
\text { AP002 } \\
\text { Kegagalan }\end{array}$ & Perbaikan & TTF \\
\hline 64 & $28 / 05 / 2008$ & $28 / 05 / 2008$ & 437 \\
64 & $05 / 07 / 2008$ & $05 / 07 / 2008$ & 38 \\
65 & $14 / 08 / 2008$ & $14 / 08 / 2008$ & 40 \\
82 & $14 / 04 / 2013$ & $22 / 04 / 2013$ & 1704 \\
83 & $08 / 08 / 2013$ & $14 / 08 / 2013$ & 108 \\
83 & $13 / 08 / 2013$ & $22 / 08 / 2013$ & 437 \\
\hline
\end{tabular}

Nilai Time To Failure antara waktu kegagalan dan perbaikan (TTF) untuk sistem 
komponen keselamatan KBE01 AA068 ditampilkan pada Tabel 7.

Tabel 7. TTF untuk KBE01 AA068

\begin{tabular}{cccc}
\hline $\begin{array}{c}\text { Teras } \\
\text { Nomor }\end{array}$ & $\begin{array}{c}\text { KBE01 AA068 } \\
\text { Kegagalan }\end{array}$ & Perbaikan & TTF \\
\hline 66 & $02 / 11 / 2009$ & $02 / 11 / 2009$ & 1537 \\
71 & $08 / 06 / 2010$ & $11 / 06 / 2010$ & 218 \\
74 & $28 / 01 / 2011$ & $01 / 02 / 2011$ & 231 \\
85 & $24 / 02 / 2014$ & $25 / 02 / 2014$ & 1119 \\
85 & $01 / 04 / 2014$ & $11 / 04 / 2014$ & 35 \\
\hline
\end{tabular}

Nilai Time To Failure antara waktu kegagalan dan perbaikan (TTF) untuk sistem komponen keselamatan SMJ10 ditampilkan pada Tabel 8.

Tabel 8. TTF untuk SMJ10

\begin{tabular}{cccc}
\hline $\begin{array}{c}\text { Teras } \\
\text { Nomor }\end{array}$ & $\begin{array}{c}\text { SMJ10 } \\
\text { Kegagalan }\end{array}$ & Perbaikan & TTF \\
\hline 55 & $30 / 09 / 2005$ & $30 / 09 / 2005$ & 10 \\
63 & $17 / 01 / 2008$ & $17 / 01 / 2008$ & 839 \\
76 & $10 / 01 / 2012$ & $11 / 01 / 2012$ & 1454 \\
78 & $04 / 06 / 2012$ & $04 / 06 / 2012$ & 145 \\
81 & $12 / 03 / 2013$ & $12 / 03 / 2013$ & 281 \\
\hline
\end{tabular}

Nilai Time To Failure antara waktu kegagalan dan perbaikan (TTF) untuk sistem komponen keselamatan JKT04 ditampilkan pada Tabel 9.

Tabel 9. TTF untuk JKT04

\begin{tabular}{cccc}
\hline $\begin{array}{c}\text { Teras } \\
\text { Nomor }\end{array}$ & $\begin{array}{c}\text { JKT04 } \\
\text { Kegagalan }\end{array}$ & Perbaikan & TTF \\
\hline 62 & $29 / 12 / 2008$ & $01 / 02 / 2009$ & 490 \\
69 & $12 / 08 / 2009$ & $17 / 12 / 2009$ & 353 \\
75 & $21 / 06 / 2011$ & $28 / 06 / 2011$ & 685 \\
76 & $05 / 12 / 2011$ & $09 / 12 / 2011$ & 171 \\
86 & $08 / 09 / 2014$ & $08 / 09 / 2014$ & 1008 \\
\hline
\end{tabular}

Nilai Time To Failure antara waktu kegagalan dan perbaikan (TTF) untuk sistem komponen keselamatan JKT02 CX811 ditampilkan pada Tabel 10.
Tabel 10. TTF untuk JKT02 CX811

\begin{tabular}{cccc}
\hline $\begin{array}{c}\text { Teras } \\
\text { Nomor }\end{array}$ & $\begin{array}{c}\text { JKT02 } \\
\text { CX811 } \\
\text { Kegagalan }\end{array}$ & Perbaikan & TTF \\
\hline 79 & $06 / 07 / 2012$ & $09 / 07 / 2012$ & 3 \\
81 & $16 / 01 / 2013$ & $18 / 01 / 2013$ & 191 \\
81 & $08 / 02 / 2013$ & $08 / 02 / 2013$ & 21 \\
83 & $18 / 07 / 2013$ & $18 / 07 / 2013$ & 160 \\
85 & $05 / 02 / 2014$ & $21 / 02 / 2014$ & 202 \\
86 & $10 / 02 / 2014$ & $10 / 02 / 2014$ & 295 \\
86 & $13 / 12 / 2014$ & $13 / 12 / 2014$ & 3 \\
\hline
\end{tabular}

Nilai Time To Failure antara waktu kegagalan dan perbaikan (TTF) untuk sistem komponen keselamatan JKT03 CX811 ditampilkan pada Tabel 11.

Tabel 11. TTF untuk JKT03 CX811

\begin{tabular}{cccc}
\hline $\begin{array}{c}\text { Teras } \\
\text { Nomor }\end{array}$ & $\begin{array}{c}\text { JKT03 } \\
\text { CX811 } \\
\text { Kegagalan }\end{array}$ & Perbaikan & TTF \\
\hline 84 & $10 / 11 / 2013$ & $10 / 11 / 2013$ & 1903 \\
86 & $13 / 10 / 2014$ & $13 / 10 / 2014$ & 337 \\
86 & $09 / 12 / 2014$ & $09 / 12 / 2014$ & 57 \\
88 & $12 / 08 / 2015$ & $12 / 08 / 2015$ & 246 \\
88 & $13 / 08 / 2015$ & $13 / 08 / 2015$ & 1 \\
\hline
\end{tabular}

Nilai Time To Failure antara waktu kegagalan dan perbaikan (TTF) untuk sistem komponen keselamatan JKT03 CX841 ditampilkan pada Tabel 12.

Tabel 12. TTF untuk JKT03 CX841

\begin{tabular}{rccc}
\hline $\begin{array}{r}\text { Teras } \\
\text { Nomor }\end{array}$ & $\begin{array}{c}\text { JKT03 } \\
\text { CX841 } \\
\text { Kegagalan }\end{array}$ & Perbaikan & TTF \\
\hline 79 & $08 / 06 / 2012$ & $19 / 06 / 2012$ & 1570 \\
81 & $18 / 01 / 2013$ & $18 / 01 / 2013$ & 213 \\
81 & $25 / 01 / 2013$ & $27 / 01 / 2013$ & 7 \\
85 & $31 / 01 / 2014$ & $16 / 02 / 2014$ & 369 \\
\hline
\end{tabular}

Uji kecocokan sebaran waktu TTF dilakukan menggunakan sebaran Eksponen, Log-Normal, Weibull dan Normal dengan uji Anderson Darling [3,15,16]. Diperoleh bahwa uji kecocokan secara keseluruhan 
menghampiri sebaran Weibull. Untuk itu dilakukan perhitungan parameter karakteristik dari sebaran yang sesuai yaitu sebaran Weibull yang mempunyai masingmasing parameter scale dan shape. Perhitungan nilai keandalan, tingkat resiko, rata-rata umur komponen pendukung sistim keselamatan menggunakan parameter scale, shape dan nilai Tahun. Perhitungan nilai shape, scale, fungsi keandalan $\mathrm{R}(\mathrm{t})$, tingkat resiko atau laju kegagalan $\mathrm{h}(\mathrm{t})$ dan rata-rata umur produk $\mathrm{E}(\mathrm{t})$ terhadap waktu $\mathrm{t}=15$ (Tahun 2020) untuk komponen BRV10 ditampilkan pada Tabel 13.

Tabel 13. R(t), h(t), E(t) untuk BRV10

\begin{tabular}{cccc}
\hline BRV10 & Tahun ke & $\mathrm{R}(\mathrm{t})$ & $\mathrm{h}(\mathrm{t})$ \\
\hline Scale $:$ & 2 & 0,9933 & 0,0034 \\
297,346 & 5 & 0,9833 & 0,0034 \\
Shape: 1 & 6 & 0,9800 & 0,0034 \\
E(t):297 & 8 & 0,9734 & 0,0034 \\
L(Inf) : 1,034 & 10 & 0,9669 & 0,0034 \\
& 10 & 0,9669 & 0,0034 \\
& 10 & 0,9669 & 0,0034 \\
\hline
\end{tabular}

Lamanya komponen mampu berfungsi sampai waktu kegagalan dinyatakan dengan rata-rata umur $\mathrm{E}(\mathrm{t})$. Diperoleh rata-rata umur komponen BRV10 adalah 297 hari. Peluang keandalan sampai 10 tahun dinyatakan dengan $\mathrm{R}(\mathrm{t})$ terhitung tahun 2005. Pada tahun 2015 keandalan 0,9669 masih diatas $95 \%$. Tingkat resiko kegagalan pertahun dinyatakan dengan laju kegagalan $h(t)$ konstan cukup kecil yaitu 0,0034 kegagalan per tahun. Sedangkan kemampuan sampai dengan kegagalan berikutnya L(Inf) adalah 1,034 tahun yang lebih lama dibandingkan dengan interval perawatan 6 bulan untuk BRV10.

Perhitungan nilai shape, scale, fungsi keandalan $\mathrm{R}(\mathrm{t})$, laju kegagalan $\mathrm{h}(\mathrm{t})$ dan ratarata umur produk $\mathrm{E}(\mathrm{t})$ komponen BRV20 ditampilkan pada Tabel 14 berikut:

Tabel 14. R(t), h(t), E(t) untuk BRV20

\begin{tabular}{cccc}
\hline BRV20 & Tahun ke & $\mathrm{R}(\mathrm{t})$ & $\mathrm{h}(\mathrm{t})$ \\
\hline Shape: 1 & 3 & 0,9892 & 0,0036 \\
Scale : & 3 & 0,9892 & 0,0036 \\
275,136 & 4 & 0,9856 & 0,0036 \\
E(t):275 & 4 & 0,9856 & 0,0036 \\
L(Inf):1,04 & 5 & 0,9820 & 0,0036 \\
& 5 & 0,9820 & 0,0036 \\
& 8 & 0,9713 & 0,0036 \\
& 9 & 0,9678 & 0,0036 \\
& 10 & 0,9643 & 0,0036 \\
& 11 & 0,9608 & 0,0036 \\
& 11 & 0,9608 & 0,0036 \\
\hline
\end{tabular}

Rata-rata umur komponen BRV20 adalah 275 hari, yaitu komponen mampu berfungsi sampai waktu kegagalan. Peluang keandalan sampai 11 tahun terhitung tahun 2005 dinyatakan $\mathrm{R}(\mathrm{t})$ sebesar 0,9608 atau 96,1\%. Laju kegagalan $h(t)$ cukup kecil yaitu sebesar 0,0036 yang merupakan tingkat risiko kegagalan per tahun. Kemampuan sampai dengan kegagalan berikutnya L(Inf) adalah 1,04 tahun yang lebih lama dibandingkan interval perawatan 6 bulan untuk BRV20.

Perhitungan nilai shape, scale, fungsi keandalan $\mathrm{R}(\mathrm{t})$, tingkat resiko atau laju kegagalan $\mathrm{h}(\mathrm{t})$ dan rata-rata umur produk $\mathrm{E}(\mathrm{t})$ komponen BRV30 ditampilkan pada Tabel 15. 
Tabel 15. R(t), h(t), E(t) untuk BRV30

\begin{tabular}{cccc}
\hline BRV30 & Tahun ke & $\mathrm{R}(\mathrm{t})$ & $\mathrm{h}(\mathrm{t})$ \\
\hline Shape: & 2 & 0,9947 & 0,0019 \\
0,71 & 2 & 0,9947 & 0,0019 \\
Scale: & 2 & 0,9947 & 0,0019 \\
305,943 & 3 & 0,9929 & 0,0017 \\
E(t): & 4 & 0,9913 & 0,0015 \\
305 & 5 & 0,9898 & 0,0014 \\
L(Inf): & 9 & 0,9847 & 0,0012 \\
1,03 & & & \\
\hline
\end{tabular}

Rata-rata umur komponen BRV30 berfungsi sampai waktu kegagalan adalah 413 hari. Peluang keandalan 9 tahun terhitung tahun 2005 dinyatakan dalam $\mathrm{R}(\mathrm{t})$ 98,47 \%. Laju kegagalan $\mathrm{h}(\mathrm{t})$ berturut-turut dari tahun ke dua ke tahun 9 cukup kecil yaitu 0,0012 merupakan tingkat risiko kegagalan per tahun. Kemampuan sampai kegagalan berikutnya L(Inf) adalah 1,03 tahun yang lebih lama dibandingkan interval perawatan 6 bulan untuk BRV30.

Perhitungan nilai shape, scale, fungsi keandalan $\mathrm{R}(\mathrm{t})$, tingkat resiko $\mathrm{h}(\mathrm{t})$ dan ratarata umur produk $\mathrm{E}(\mathrm{t})$ untuk komponen KBE01 AP001 ditampilkan Tabel 16.

Tabel 16. R(t), h(t), E(t) untuk KBE01 AP001

\begin{tabular}{cccc}
\hline $\begin{array}{c}\text { KBE01 } \\
\text { AP001 }\end{array}$ & Tahun ke & $\mathrm{R}(\mathrm{t})$ & $\mathrm{h}(\mathrm{t})$ \\
\hline Shape: 1 & 3 & 0,9932 & 0,0023 \\
Scale: & 4 & 0,9910 & 0,0023 \\
440,724 & 6 & 0,9865 & 0,0023 \\
E(t):440 & 8 & 0,9820 & 0,0023 \\
L(Inf):1,025 & 10 & 0,9776 & 0,0023 \\
& 10 & 0,9776 & 0,0023 \\
& 10 & 0,9776 & 0,0023 \\
& 10 & 0,9776 & 0,0023 \\
& 11 & 0,9756 & 0,0023 \\
\hline
\end{tabular}

Rata-rata umur komponen KBE01 AP001 mampu berfungsi sampai waktu kegagalan adalah 440 hari. Peluang keandalan sampai 11 tahun terhitung tahun 2005 dinyatakan dalam $\mathrm{R}(\mathrm{t})$ 97,56 \%. Laju kegagalan $\mathrm{h}(\mathrm{t})$, konstan yaitu 0,0023 merupakan tingkat risiko kegagalan per tahun. Kemampuan sampai dengan kegagalan berikutnya L(Inf) adalah 1,025 tahun lebih lama dibandingkan interval perawatan 6 bulan untuk KBE01 AP001.

Perhitungan nilai shape, scale, fungsi keandalan $\mathrm{R}(\mathrm{t})$, laju kegagalan $\mathrm{h}(\mathrm{t})$ dan ratarata umur produk $\mathrm{E}(\mathrm{t})$ komponen KBE01 AP002 terhadap waktu dinyatakan Tabel 17.

Tabel 17. R(t), h(t), E(t) untuk KBE01 AP002

\begin{tabular}{cccc}
\hline $\begin{array}{c}\text { KBE01 } \\
\text { AP002 }\end{array}$ & $\begin{array}{c}\text { Tahun } \\
\text { ke }\end{array}$ & $\mathrm{R}(\mathrm{t})$ & $\mathrm{h}(\mathrm{t})$ \\
\hline Shape $: 0,77$ & 4 & 0,9898 & 0,0026 \\
Scale:391,15 & 4 & 0,9898 & 0,0026 \\
E(t) $: 391$ & 4 & 0,9898 & 0,0026 \\
L(inf) $: 1,023$ & 9 & 0,9773 & 0,0026 \\
& 9 & 0,9773 & 0,0026 \\
& 9 & 0,9773 & 0,0026 \\
\hline
\end{tabular}

Rata-rata umur komponen KBE01 AP002 mampu berfungsi sampai waktu kegagalan adalah 391 hari. Peluang keandalan sampai 9 tahun terhitung tahun 2005 dinyatakan dalam $\mathrm{R}(\mathrm{t})$ sebesar 97,73 \%. Laju kegagalan $\mathrm{h}(\mathrm{t})$ berturut-turut sampai tahun ke 9 terhitung 2005 cukup kecil yaitu 0,0026, merupakan tingkat risiko kegagalan per tahun. Kemampuan sampai dengan kegagalan berikutnya L(Inf) adalah 1,023 tahun yang lebih lama dibandingkan interval perawatan 1 tahun untuk KBE01 AP002. 
Perhitungan nilai shape, scale, fungsi keandalan $\mathrm{R}(\mathrm{t})$, laju kegagalan $\mathrm{h}(\mathrm{t})$ dan ratarata umur $\mathrm{E}(\mathrm{t})$ komponen KBE01 AA068 terhadap waktu dinyatakan Tabel 18.

Tabel 18. R(t), h(t), E(t) untuk KBE01 AA068

\begin{tabular}{cccc}
\hline KBE01 & $\begin{array}{c}\text { Tahun } \\
\text { ke }\end{array}$ & $\mathrm{R}(\mathrm{t})$ & $\mathrm{h}(\mathrm{t})$ \\
AA068 & 5 & 0,9917 & 0,0017 \\
Shape: 0,91 & 6 & 0,9901 & 0,0017 \\
Scale:599,9 & 7 & 0,9884 & 0,0017 \\
E(T):599 & 7 & 0,9835 & 0,0017 \\
L(Inf) $: 1,023$ & 10 & 0,9835 & 0,0017 \\
& 10 & &
\end{tabular}

Rata-rata umur komponen KBE01 AA068 mampu berfungsi sampai waktu kegagalan adalah 599 hari. Peluang keandalan sampai 10 tahun terhitung tahun 2005 dinyatakan dalam $\mathrm{R}(\mathrm{t})$ sebesar 98,35\%. Laju kegagalan $\mathrm{h}(\mathrm{t})$ konstan cukup kecil yaitu 0,0017 merupakan tingkat risiko kegagalan per tahun. Kemampuan sampai kegagalan berikutnya L(Inf) adalah 1,023 tahun yang lebih lama dibandingkan interval perawatan 1 bulan untuk KBE01 AA068.

Perhitungan nilai shape, scale, fungsi keandalan $\mathrm{R}(\mathrm{t})$, laju kegagalan $\mathrm{h}(\mathrm{t})$ dan ratarata umur produk $\mathrm{E}(\mathrm{t})$ untuk komponen JKT04 terhadap waktu dinyatakan pada Tabel 19.

Tabel 19. R(t), h(t), E(t) untuk JKT04

\begin{tabular}{cccc}
\hline JKT04 & $\begin{array}{c}\text { Tahun } \\
\text { ke }\end{array}$ & $\mathrm{R}(\mathrm{t})$ & $\mathrm{h}(\mathrm{t})$ \\
\hline Shape: 1 & 4 & 0,9925 & 0,0019 \\
Scale:531,38 & 5 & 0,9906 & 0,0019 \\
E(t):531 & 7 & 0,9869 & 0,0019 \\
L(Inf) $: 1,0188$ & 7 & 0,9869 & 0,0019 \\
& 10 & 0,9814 & 0,0019 \\
\hline
\end{tabular}

Rata-rata umur komponen JKT04 berfungsi sampai kegagalan adalah 531 hari. Peluang keandalan sampai 10 tahun terhitung tahun 2005 dinyatakan dalam $\mathrm{R}(\mathrm{t})$ sebesar 98,14 $\%$. Laju kegagalan $\mathrm{h}(\mathrm{t})$ konstan cukup kecil yaitu 0,0019, merupakan tingkat risiko kegagalan per tahun. Kemampuan sampai kegagalan berikutnya L(Inf) adalah 1,0019 tahun yang lebih lama dibandingkan interval perawatan 1 bulan untuk JKT04.

Perhitungan shape, scale, fungsi keandalan $\mathrm{R}(\mathrm{t})$, laju kegagalan $\mathrm{h}(\mathrm{t})$ dan ratarata umur komponen SMJ10 terhadap waktu dinyatakan padaTabel 20,

Tabel 20. R(t), h(t), E(t) untuk SMJ10

\begin{tabular}{cccc}
\hline SMJ10 & $\begin{array}{l}\text { Tahu: } \\
\text { ke }\end{array}$ & $\mathrm{R}(\mathrm{t})$ & $\mathrm{h}(\mathrm{t})$ \\
\hline Shape:0,78 & 1 & 0,9979 & 0,0021 \\
Scale:482,511 & 4 & 0,9917 & 0,0021 \\
$\mathrm{E}(\mathrm{t}): 482$ & 8 & 0,9836 & 0,0021 \\
L(Inf) $: 1,019$ & 8 & 0,9836 & 0,0021 \\
& 9 & 0,9815 & 0,0021 \\
\hline
\end{tabular}

Rata-rata umur komponen SMJ10 berfungsi sampai kegagalan adalah 482 hari. Peluang keandalan $\mathrm{R}(\mathrm{t})$ sampai tahun ke 9 sebesar 98,15\%. Laju kegagalan per tahun $\mathrm{h}(\mathrm{t})$ konstan cukup kecil yaitu 0,0021 . Kemampuan sampai kegagalan berikutnya L(Inf) adalah 1,019 tahun yang lebih lama dibandingkan perawatan 1 tahun untuk SMJ10.

Perhitungan shape, scale, fungsi keandalan $\mathrm{R}(\mathrm{t})$, laju kegagalan $\mathrm{h}(\mathrm{t})$ dan ratarata umur produk $\mathrm{E}(\mathrm{t})$ komponen JKT02 
CX811 terhadap waktu dinyatakan pada Tabel 21,

Tabel 21. R(t), h(t), E(t) untuk JKT02 CX811

\begin{tabular}{cccc}
\hline JKT02 & $\begin{array}{c}\text { Tahun } \\
\text { ke }\end{array}$ & $\mathrm{R}(\mathrm{t})$ & $\mathrm{h}(\mathrm{t})$ \\
CX811 & 8 & 0,9278 & 0,0094 \\
Shape:0,73 & 8 & 0,9191 & 0,0094 \\
Scale: 106,72 & 9 & 0,9191 & 0,0094 \\
E(T):106 & 9 & 0,9191 & 0,0094 \\
L(Inf): 1,094 & 9 & 0,9105 & 0,0094 \\
& 10 & 0,9105 & 0,0094 \\
& 10 & 0,9105 & 0,0094 \\
\hline
\end{tabular}

Rata-rata umur komponen JKT02 CX811 mampu berfungsi sampai waktu kegagalan adalah 106,7 hari. Peluang keandalan sampai 10 tahun dinyatakan dalam $\mathrm{R}(\mathrm{t})$ sebesar 91,05 \%. Laju kegagalan $\mathrm{h}(\mathrm{t})$ per tahun sampai tahun ke 10 adalah 0,0094. Kemampuan sampai dengan kegagalan berikutnya L(Inf) adalah 1,094 tahun yang lebih lama dibandingkan interval perawatan 6 bulan.

Perhitungan shape, scale, fungsi keandalan $\mathrm{R}(\mathrm{t})$, laju kegagalan $\mathrm{h}(\mathrm{t})$ dan ratarata umur produk E(t) komponen JKT03 CX811 terhadap waktu dinyatakan pada Tabel 22.

Tabel 22. $\mathrm{R}(\mathrm{t}), \mathrm{h}(\mathrm{t}), \mathrm{E}(\mathrm{t})$ untuk JKT03 CX811

\begin{tabular}{cccc}
\hline JKT03 & Tahun & & \\
CX811 & ke & $\mathrm{R}(\mathrm{t})$ & $\mathrm{h}(\mathrm{t})$ \\
\hline Shape:0,5302 & 9 & 0,9714 & 0,0032 \\
Scale:310,281 & 10 & 0,9683 & 0,0032 \\
E(t):310 & 10 & 0,9683 & 0,0032 \\
L(Inf):1,035 & 11 & 0,9652 & 0,0032 \\
& 11 & 0,9652 & 0,0032 \\
\hline
\end{tabular}

Rata-rata umur komponen JKT03 CX811 mampu berfungsi sampai waktu kegagalan adalah 310 hari. Peluang keandalan sampai 11 tahun terhitung tahun 2005 dinyatakan dalam $\mathrm{R}(\mathrm{t})$ sebesar 96,52 \%. Laju kegagalan $\mathrm{h}(\mathrm{t})$ per tahun adalah konstan yaitu 0,0032. Kemampuan sampai dengan kegagalan berikutnya $\mathrm{L}(\mathrm{Inf})$ adalah 1,035 tahun yang lebih lama dibandingkan interval perawatan 6 bulan.

Perhitungan shape, scale, fungsi keandalan $\mathrm{R}(\mathrm{t})$, laju kegagalan $\mathrm{h}(\mathrm{t})$ dan ratarata umur produk $\mathrm{E}(\mathrm{t})$ komponen JKT03 CX841 terhadap waktu dinyatakan pada Tabel 23,

Tabel 23. R(t), h(t), E(t) untuk JKT03 CX841

\begin{tabular}{cccc}
\hline JKT03 & Tahun & & \\
CX841 & ke & $\mathrm{R}(\mathrm{t})$ & $\mathrm{h}(\mathrm{t})$ \\
\hline Shape: 0,67227 & 8 & 0,9814 & 0,0024 \\
Scale: 426,33 & 9 & 0,9791 & 0,0024 \\
E(t):426 & 9 & 0,9791 & 0,0024 \\
L(Inf): 1,0235 & 10 & 0,9768 & 0,0024 \\
\hline
\end{tabular}

Rata-rata umur komponen JKT03 CX841 mampu berfungsi sampai waktu kegagalan adalah 426 hari. Peluang keandalan 10 tahun terhitung tahun 2005 dinyatakan dalam $\mathrm{R}(\mathrm{t})$ sebesar 97,68 \%. Laju kegagalan $\mathrm{h}(\mathrm{t})$ konstan yaitu 0,0024, per tahun. Kemampuan berfungsinya komponen sampai kegagalan berikutnya L(Inf) adalah 1,0235 tahun yang lebih lama dibandingkan dengan interval perawatan 6 bulan. Berarti kondisi komponen JKT03 CX841 masih andal sampai waktu perawatan berikutnya. 
Kemampuan masing-masing komponen pendukung sistem keselamatan ditunjukkan pada Tabel 24.

Tabel 24. Kemampuan komponen pendukung keselamatan sampai kegagalan berikutnya

\begin{tabular}{ccc}
\hline $\begin{array}{c}\text { Komponen } \\
\text { Keselamatan }\end{array}$ & $\begin{array}{c}\text { Kegagalan } \\
\text { Berikutnya } \\
\text { L(Inf) (Tahun) }\end{array}$ & $\begin{array}{c}\text { Interval } \\
\text { Perawata } \\
\text { n }\end{array}$ \\
\hline BRV10 & 1,007 & 6 bulan \\
BRV20 & 1,007 & 6 bulan \\
BRV30 & 1,030 & 6 bulan \\
KBE01 AP001 & 1,025 & 6 bulan \\
KBE01 AP002 & 1,023 & 6 bulan \\
KBE01 AA068 & 1,023 & 1 bulan \\
SMJ10 & 1,019 & 1 tahun \\
JKT04 & 1,018 & 6 bulan \\
JKT02 CX811 & 1,094 & 6 bulan \\
JKT03 CX811 & 1,035 & 6 bulan \\
JKT03 CX841 & 1,023 & 6 bulan \\
\hline
\end{tabular}

Dari Tabel 24 diperoleh bahwa kemampuan berfungsinya komponen tersebut diatas untuk lebih dari tahun 2020 atau L(Inf) adalah lebih dari 1 tahun dan hal ini masih melebihi dari interval waktu perawatan berikutnya yang ditetapkan (Tabel 1). Berarti masingmasing komponen masih mampu berfungsi sampai minimal tiba waktu perawatan berikutnya. Oleh sebab itu perawatan komponen merupakan faktor yang penting dan tetap perlu dilakukan secara berkala.

\section{KESIMPULAN}

Evaluasi umur komponen telah dilakukan terhadap komponen sistem keselamatan RSG-GAS. Melalui uji kesesuaian dan perhitungan parameter diperoleh bahwa sebaran waktu kegagalan mengikuti sebaran Weibull. Telah dilakukan perhitungan peluang keandalan, laju kegagalan berkaitan faktor keselamatan dan rata rata umur serta peluang komponen akan gagal pada waktu tertentu. Diperoleh bahwa kemampuan berfungsinya komponen pendukung sistim keselamatan lebih dari tahun 2020 sampai kegagalan berikutnya adalah lebih dari 1 tahun. Hal ini masih melebihi batas interval waktu perawatan yang ditetapkan. Dengan demikian masingmasing komponen pendukung sistem keselamatan secara keseluruhan dapat berfungsi sampai tiba waktu perawatan berikutnya. Walaupun demikian perawatan komponen merupakan hal yang penting dan perlu dilakukan secara berkala.

\section{UCAPAN TERIMAKASIH}

Penulis mengucapkan terimakasih atas dukungan anggaran DIPA tahun $2020 \mathrm{di}$ PTKRN sehingga terlaksananya kegiatan penelitian ini.

\section{DAFTAR PUSTAKA}

[1]. SUSMIKANTI M., SAEPUDIN A., DESWANDRI. Database system development for component reliability of RSG-GAS based on WEB. in: Prosiding SENTEN, Batam. 2016. 
[2]. SUSMIKANTI M., SAEPUDIN A., ADRIAN $\mathrm{S}$ et al. Database system development for operational parameter of RSG-GAS based on WEB. in: Prosiding SENTEN, Makasar. 2017.

[3]. SUSMIKANTI M., HARTINI E., SAEPUDIN A. et al. Component analysis of purification system of RSG-GAS. Jurnal Pengembangan Energi Nuklir. 2018. 20(1): 31-39.

[4]. PUSAT REAKTOR SERBA GUNA. Klasifikasi Peralatan/Komponen RSG-GAS Revisi 2, Unit Jaminan Mutu - PRSG, BATAN, 1997.

[5]. PUSAT REAKTOR SERBA GUNA. Laporan Operasi Reaktor RSG-GAS, Teras 55-88, Unit Jaminan Mutu PRSG, BATAN, 2005-2015.

[6]. KIM T.R. Safety classification of systems, structures and components for pool type research reactors. Nucl. Eng. and Tech. 2016. 48(1): 10151021.

[7]. LIAN G. OTAYA. Distribusi probabilitas Weibull dan aplikasinya (pada persoalan keandalan (reliability) dan analisis rawatan (mantainability). Jurnal Manajemen Pendidikan Islam. 2016. 4(2).

[8]. SUDARNO. Karakteristik umur produk model Weibull. Media Statistika. 2009. 2(2): 105-110.
[9]. FAMELA B. D., LUKITOSARI V., DOCTORINA W. F. Analisa penentuan sisa umur bearing menggunakan fungsi Mean Residual Life (studi kasus pada mesin Sakurai Oliver-66 CV. Bintang Cakra). J. Math. and Its Appl. 2017. 14 (2): 127-143.

[10]. POBOČÍKOVÁ I., MICHALKOVÁ M. Application of four probability distributions for wind speed modeling. Procedia Eng. 2017. 192: 713-718.

[11]. FARIDAFSHIN F., GRECHUK B., NAESS A. Calculating exceedance probabilities using a distributionally robust method. Structural Safety. 2017. 67: 132-141.

[12]. MEKONNEN Y., ABURBU H., SARWAT A. Life cycle prediction of sealed lead acid batteries based on a Weibull model. Journal of Energy Storage. 2018. 18: 467-475.

[13]. DATSIOU K.C., OVEREND M. Weibull parameter estimation and goodness-of-fit for glass strength data. Structural Safety. 2018. 73: 2941.

[14]. HARTINI E., SUSMIKANTI M. Reliability analysis for critical components of RSG_GAS primary cooling system. Tri Dasa Mega. 2018. 22(2): 71-79. 
[15]. SUSMIKANTI M., HARTINI E., PURWADI. Analisis keandalan komponen sistim keselamatan Reaktor Serba Guna G.A. Siwabessy. in: Prosiding SENTEN, Padang, 2019.

[16]. SUSMIKANTI M., HARTINI E., SAEPUDIN A. et al. Analisis keandalan perawatan sub-sistem elektrik, instrumentasi dan kontrol RSG-GAS. Sigma Epsilon. 2019. $23(2)$. 